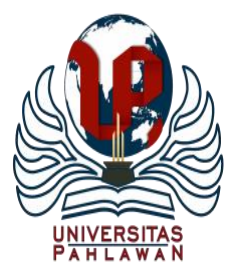

Jurnal Abdidas Volume 2 Nomor 3 Tahun 2021 Halaman 634-645

JURNAL ABDIDAS

http://abdidas.org/index.php/abdidas

\title{
Pendampingan Pembuatan Mural Edukasi sebagai Upaya Meningkatkan Minat Belajar Siswa Sekolah Dasar dengan Konsep Belajar dan Bermain
}

\author{
Zhilli Izzadati Khairuni $^{1}$, Liana Atika ${ }^{2}$, Rumila Harahap ${ }^{3}$, Kemala Jeumpa ${ }^{4}$ \\ D-3 Teknik Sipil, Fakultas Teknik, Universitas Negeri Medan, Indonesia ${ }^{1,3,4}$ \\ Pendidikan Teknik Bangunan, Fakultas Teknik, Universitas Negeri Medan, Indonesia ${ }^{2}$ \\ E-mail : zhilli_ft@unimed.ac.id ${ }^{1}$, Liana_atika@unimed.ac.id ${ }^{2}$, Rumi_harahap@yahoo.com ${ }^{3}$, \\ Ipa_jeumpa@gmail.com ${ }^{4}$
}

\begin{abstract}
Abstrak
Target kegiatan pengabdian adalah sebuah sekolah yang terletak di pinggiran Kota Medan tepatnya Perumnas Simalingkar Medan Tuntungan. Salah satu upaya yang dapat dilakukan untuk mewujudkan visual yang baik dan menarik adalah memperbaiki fisik bangunan. Upaya tersebut berupa aplikasi seni mural, selain dianggap memperindah tampilan fisik bangunan, seni mural ini juga dapat memperkuat karakter sebuah kawasan. Metode yang dilakukan adalah dengan metode sosialisasi, membuat konsep desain, kemudian praktik dengan bimbingan pembuatan mural, serta monitoring dan evaluasi. Mural yang dihasilkan dalam bentuk mural edukasi dengan beberapa ragam pengetahuan. Hasil kegiatan ini berupa adanya peningkatan ekonomi, peningkatan ilmu seni bagi mitra terpilih sekaligus memperbaiki visual bangunan sekolah. Evaluasi kegiatan ini menghasilkan umpan balik yang positif, potensi keberlanjutan kegiatan pembuatan mural ini bisa dilakukan pada lokasi yang lain dengan konsep atau tema yang berbeda sehingga semakin banyak masyarakat yang mendapat edukasi dan keterampilan dalam memperbaiki visual bangunan. Pengabdian masyarakat berupa pembuatan mural disekolah ini terlaksana dengan baik sesuai dengan yang telah direncanakan, dari hasil sosialisasi sampai dengan proses pengerjaan para peserta sangat antusias dan sangat senang bisa mempelajari cara-cara dalam pembuatan mural. Peserta mendapat keterampilan baru yang belum pernah diperoleh sebelumnya sebagai bekal dalam membuat suatu inovasi juga memberi warna baru pada tampilan visual sekolah dalam meningkatkan proses belajar mengajar.
\end{abstract}

Kata kunci: visual, mural, edukasi, sekolah, seni

\begin{abstract}
The target of this community service activity is a school which located of the edge of Medan City, be precise, Perumnas Simalingkar Medan Tuntungan. One of the efforts that can made to create good and attractive visuals is to improve the physical building. This effort is in the form of mural art applications, apart from being considered as beautifying the physical appearance of the building, this mural art can also strengthen the character of an area. The method used is the socialization method, making design concepts, then practicing with the guidance making murals, as well as monitoring and evaluation. The outcome of the activities it will be an increase in economic, an increase in the science of the art for partner elected and improve visual school buildings. The evaluation of this activity resulted in positive feedback, the potential for sustainability of this mural-making activity could be done in other locations with different concepts or themes so that more and more people will receive education and skills in improving the visuals of buildings. The community service in the form of making murals at this school was carried out well as planned, from the results of the socialization to the process of making the participants very enthusiastic and very happy to be able to learn ways to make murals. Participants gain new skills that have never been obtained before as a provision in making an innovation as well as giving a new color to the visual appearance of the school in improving the teaching and learning process.
\end{abstract}

Keywords: Visual, mural, education, school, art.

Copyright (c) 2021 Zhilli Izzadati Khairuni, Liana Atika, Rumila Harahap, Kemala Jeumpa $\triangle$ Corresponding author

Address : Jalan Lukah no 4 LK IV Medan Amplas

Email : zhilli_ft@unimed.ac.id

DOI : https://doi.org/10.31004/abdidas.v2i3.335

ISSN 2721- 9224 (Media Cetak)

ISSN 2721- 9216 (Media Online) 
635 Pendampingan Pembuatan Mural Edukasi sebagai Upaya Meningkatkan Minat Belajar Siswa Sekolah Dasar dengan Konsep Belajar dan Bermain- Zhilli Izzadati Khairuni, Liana Atika, Rumila Harahap, Kemala Jeumpa

DOI: https://doi.org/10.31004/abdidas.v2i3.335

\section{PENDAHULUAN}

Yayasan perguruan Ar-ridha adalah salah satu sekolah Islam yang berada di Perumnas Simalingkar, Kecamatan Medan Tuntungan, Kabupaten Deli Serdang, Kota Medan. Berdiri pada tahun 2000, di Jalan Karet Raya No. 68 AA Perumnas Simalingkar. Sekolah ini sempat menjadi pilihan masyarakat setempat dikarenakan lokasi yang strategis dan kualitas guru-guru yang baik. Perkembangan dunia pendidikan yang semakin meningkat menyebabkan banyak sekolahsekolah swasta bermunculan. Hal ini menjadi salah satu pertimbangan orang tua dalam memilih sekolah, salah satunya fasilitas. Pada saat ini, jika diamati terdapat beberapa gedung sekolah yang mulai kurang perawatan, sehingga kegiatan para murid menjadi terganggu salah satu contoh kondisi cat yang terkelupas, atap bocor atau lantai yang pecah-pecah (Wahyudi et al., 2017). Sekolah yang menjadi objek pengabdian berada di pinggir jalan besar, sehingga memudahkan akses kendaraan, terjangkau oleh kendaraan yang lalu lalang akan tetapi kurang menarik untuk dilihat. Berikut ini adalah tampilan sekolah berdasarkan pengamatan sementara. Tampilan fasad bangunan pada sebuah kawasan sekolah memiliki peran penting untuk membangun sebuah karakter visual kawasan yang dapat menggambarkan identitas citra kawasan. Sebuah karakter tersebut akan memudahkan orang dalam mengenali sebuah kawasan (Harani \& Motic, 2017).
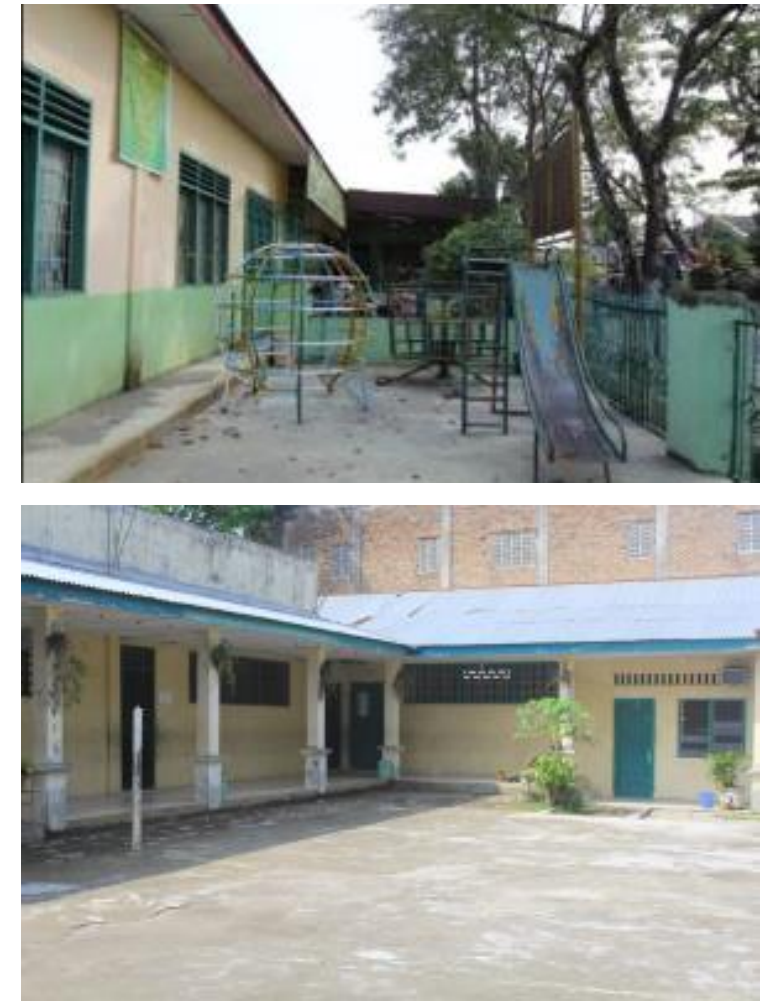

Gambar 1. Kondisi Sekolah sebagai Mitra PKM

Gambar sekolah ini memperlihatkan lokasi sekolah yang berapa di pinggir jalan besar. Sekolah ini memiliki halaman yang luas sebagai area bermain dan juga memiliki lapangan upacara yang digunakan sebagai lapangan olahraga. Jika dilihat dari kelengkapan fasilitas sebuah sekolah seperti lapangan, area bermain, mushalla dan sebagainya. Maka sekolah ini termasuk sekolah yang memenuhi syarat fasilitas yang baik, hanya saja perawatan yang kurang disiplin oleh pengelola/pengurus sekolah tersebut. Lokasi yang dipilih adalah sebuah sekolah dengan tingkat penurunan siswa yang terjadi dari tahun ke tahun, hal ini menyebabkan penurunan kualitas dan kuantitas manajemen sekolah dalam pengelolaan biaya internal, sehingga biaya operasional untuk perawatan sekolah tidak dapat dialokasikan. Jika 
636 Pendampingan Pembuatan Mural Edukasi sebagai Upaya Meningkatkan Minat Belajar Siswa Sekolah Dasar dengan Konsep Belajar dan Bermain- Zhilli Izzadati Khairuni, Liana Atika, Rumila Harahap, Kemala Jeumpa

DOI: https://doi.org/10.31004/abdidas.v2i3.335

hal ini dibiarkan maka dapat diprediksi sekolah akan ditutup. Dari hasil analisa sementara pengusul melihat kondisi sekolah yang sudah mulai tidak terawat dan ingin memberikan solusi untuk menampilkan wajah baru sekolah dengan konsep seni/art yang dituangkan dalam bentuk mural edukasi. Selain memperbaiki visual pada sekolah, diharapkan mural tersebut dapat bermanfaat bagi guru dan siswa untuk menambah minat belajar. Dalam suatu program pengembangan dan pembangunan lingkungan, peran serta masyarakat dituntut lebih aktif dan adanya kesadaran rasa memiliki. Masyarakat berhak dan dapat berperan dalam hal-hal pengambilan keputusan, pelaksanaan, pengawasan, evaluasi, dan pada akhirnya masyarakat juga berhak menikmati hasil dan manfaatnya. Inilah yang dimaksud dengan partisipasi masyarakat dalam sebuah pembangunan lingkungannya (Yusuf, 2014).

Hasil analisa situasi yang telah dijabarkan, diketahui bahwa permasalahan yang ada di sekolah ini sebagai berikut: 1) keberadaan sekolah yang pernah memiliki masa kejayaannya perlahan-lahan sirna dengan banyaknya bermunculan sekolahsekolah swasta lain yang lebih menarik secara tampilan fisik, 2) pengelola/pengurus sekolah belum memiliki ide khusus untuk memperindah tampilan fisik bangunan, dan perawatan sebatas mengecat bangunan setiap tahunnya. Ditambah lagi dengan meredupkan perekonomian sekolah tersebut yang menyebabkan terbatasnya biaya operasional untuk perawatan gedung, 3) kondisi sekolah yang minim edukasi seperti taman bermain yang mencangkup pada konsep visual, audio dan kinestetik. Sekolah, guru-guru dan fasilitas merupakan sarana utama yang dapat menentukan perkembangan pada potensi seorang anak didik sedangkan prasarana merupakan suatu bagian pendukung dari kegiatan tersebut. Guru adalah aktor utama dalam kegiatan pendidikan yang bergantung terhadap prasarana sekolah yang tersedia, seperti: toilet, kantin, dan khususnya untuk pendidikan anak usia dini adalah ruang bermain anak (Hantono et al., 2020).

Solusi permasalahan mitra yang menjadi prioritas pengusul PKM adalah sebagai berikut: 1) membuat sebuah survei ke beberapa sekolah (maks.2-3 sekolah) yang berada berdekatan untuk mengetahui kondisi penurunan minat masyarakat terhadap sekolah yang menjadi target pengabdian, 2) memberi pemahaman dan membuka wawasan kepada pengelola/pengurus sekolah mengenai pentingnya tampilan fisik bangunan terhadap penilaian orang tua dalam memilih sekolah anak. Dengan pemahaman tersebut dapat meningkatkan ekonomi sekolah, 3) memberi pemahaman dan wawasan bagi pengelola, guru-guru terhadap edukasi untuk meningkatkan kemampuan anak melalui visual, audio dan kinestetik yang bisa diberikan di luar kelas agar guru dan siswa dapat berinteraksi dengan baik. Melalui penampilan aneka variasi pada warna dan bentuk gambar, serta garis atau yang lain, beragam ilustrasi dengan pengaturannya diselang-seling tersebut akan membuat dinding mempunyai daya tarik tersendiri, khususnya pada anak-anak (Yasa, 2020). 
637 Pendampingan Pembuatan Mural Edukasi sebagai Upaya Meningkatkan Minat Belajar Siswa Sekolah Dasar dengan Konsep Belajar dan Bermain- Zhilli Izzadati Khairuni, Liana Atika, Rumila Harahap, Kemala Jeumpa

DOI: https://doi.org/10.31004/abdidas.v2i3.335

\section{METODE}

Setelah memperoleh data dan informasi yang akurat dari permasalahan yang dialami oleh sekolah yang menjadi target pengabdian. Selanjutnya dasar tersebut dijadikan dasar bagi tim untuk mencari solusi yang paling tepat yang nantinya akan digunakan untuk memecahkan masalah yang akan dihadapi. Setelah melakukan analisis, maka tim memutuskan solusi yang digunakan yaitu memberikan sosialisasi dan pendampingan yang berkaitan dengan bidang ilmu arsitektur.

Kegiatan ini dilaksanakan pada:

Lokasi: Yayasan perguruan Ar-ridha, Jalan Karet Raya No. 68 AA, Perumnas Simalingkar, Kecamatan Medan Tuntungan, Kabupaten Deli Serdang Kota Medan.

Waktu: Pelaksanaan kegiatan dilakukan selama 4 bulan (Agustus s.d Oktober 2020)

Adapun metode yang akan dilakukan dalam kegiatan pengabdian masyarakat ini adalah sebagai berikut: 1) metode ceramah atau presentasi berkaitan dengan pengenalan konsep mural. Bahan ceramah (presentasi) diberikan pada peserta. Setelah selesai ceramah dilanjutkan dengan diskusi (tanya jawab) dan praktik langsung di lapangan, 2) metode demonstrasi meliputi pengenalan langkahlangkah pembuatan mural serta berbagai tema desain yang dapat diterapkan, 3) metode praktik meliputi pendampingan pembuatan mural pada dinding yang telah ditentukan sebagai upaya perbaikan visual sekolah dengan bimbingan pelaksana kegiatan dan mitra mural. Praktik secara langsung juga merupakan metode yang digunakan dalam penyampaian materi dengan memberikan gambaran-gambaran seni/art pada fisik bangunan dan praktik aplikasi seni/art dalam bentuk mural di perlihatkan langsung kepada guru dan pengelola sekolah yang mengikuti pelatihan ini (Thamrin \& Noviana, 2020), 4) metode tanya jawab dan diskusi antara tim PKM dan peserta, 5) metode evaluasi berupa umpan balik dari peserta pengabdian masyarakat, yaitu pengelola dan guruguru sekolah.

Prosedur kerja untuk mendukung realisasi solusi yang ditawarkan, maka terlebih dahulu melakukan observasi awal di lapangan melakukan pendekatan melalui wawancara dan menemukan fenomena permasalahan. Setelah observasi dan sosialisasi lalu dilakukan pengkajian permasalaan dan menemukan solusi yang hendak ditawarkan, selanjutnya menyusun prioritas tahap-tahap pelaksanaan dan selanjutnya barulah melakukan pengabdian dengan memberikan penyuluhanpenyuluan. Terakhir adalah melakukan evaluasi hasil dengan mengobservasi kembali ke masyarakat (Wicandra et al., n.d.).

Tahap pembuatan mural terbagi dalam beberapa langkah, yaitu sebagai berikut:

1. Tahap Persiapan

a. Menentukan tema (konsep) lukisan yang akan dibuat di dinding. Tema disesuaikan dengan kondisi kawasan.

b. Membuat gambar (sketsa desain) sesuai dengan tema yang ditentukan dan ukuran bidang dinding yang akan dilukis. Sketsa ini berfungsi untuk menjelaskan detail-detail 
638 Pendampingan Pembuatan Mural Edukasi sebagai Upaya Meningkatkan Minat Belajar Siswa Sekolah Dasar dengan Konsep Belajar dan Bermain- Zhilli Izzadati Khairuni, Liana Atika, Rumila Harahap, Kemala Jeumpa

DOI: https://doi.org/10.31004/abdidas.v2i3.335

gambar yang akan diterapkan agar sesuai dengan ekspektasi peserta PKM.

c. Membersihkan dan mengamplas dinding, hal ini dilakukan untuk memperkecil poripori dinding sehingga cat dasar mudah menyerap. Dinding yang akan dilukis harus benar-benar bersih dari debut atau kotoran lain yang akan mengganggu tampilan mural.

d. Setelah seluruh dinding bersih, lapisi dinding dengan warna dasar yang sudah dikonsepkan di awal penentuan tema. Tujuannya adalah untuk memperkuat daya lekat cat berikutnya.

\section{Tahap Melukis}

a. Tahap selanjutnya adalah melukis, dimulai dengan membuat pola gambar di dinding sesuai dengan sketsa desain yang sudah dibuat sebelumnya dengan menggunakan pensil/kapur tulis, untuk menghindari kesalahan sehingga mudah diperbaiki. Gambar yang di aplikasikan di dinding terkadang tidak sama persis dengan sketsa karena sistem penggambaran manual, sehingga proses ini sering terjadi penyesuaian.

b. Batasi bidang dinding dengan plester/lakban kertas agar lukisan rapi dan mencegah cipratan cat. Pada kasus dinding sekolah di plester pada bagian kusen-kusen jendala.

c. Mulai sapukan cat tembok secara bertahap, mengikut desain yang sudah dibuat. Selesaikan lukisan pada bagian background lebih dulu, kerjakan objek depan (forward) di proses akhir (finishing).

\section{Tahap Finishing}

Tahap akhir dari pembuatan mural ini adalah melapisi hasil gambar/lukisan dengan finishing vernis jenis doff agar tidak mengkilap saat terkena sinar lampu pada malam hari. Pada tahap ini peserta tidak diperkenankan melakukan sendiri akan tetapi dipandu oleh mitra mural yaitu mahasiswa Pendidikan Seni Rupa UNIMED yang sudah terbiasa membuat mural pada dindingdinding.

Rencana kegiatan tersebut terdapat beberapa kendala yang dapat diatasi selama proses kegiatan berlangsung, di mana kondisi pandemi yang disebabkan COVID-19, sehingga ada hal-hal serta kegiatan yang tidak dapat dilaksanakan sebagaimana semestinya. Kendala-kendala tersebut dapat diatasi dengan proses diskusi antara tim PKM dan pengelola sekolah. Selain itu, kondisi pandemi tersebut mempermudah kegiatan dikarenakan sekolah tempat dilakukan kegiatan PKM mengikuti aturan pemerintah untuk menerapkan sistem belajar dari rumah. Hal ini yang memperlancar proses pengecatan dinding sekolah tanpa distraksi dari murid-murid sekolah.

\section{HASIL DAN PEMBAHASAN}

\section{Mural dan Perkembangannya}

Mural merupakan sebuah lukisan yang besar pada sebuah dinding, namun mural tidak sama dengan karya lukis. Terdapat syarat khusus sebuah karya dapat dikatakan sebagai sebuah karya mural, yaitu kaitannya dengan arsitektur/bangunan, baik dari sisi desain (mempunyai unsur estetika), maupun usia serta perawatannya dan juga dari sisi 
639 Pendampingan Pembuatan Mural Edukasi sebagai Upaya Meningkatkan Minat Belajar Siswa Sekolah Dasar dengan Konsep Belajar dan Bermain- Zhilli Izzadati Khairuni, Liana Atika, Rumila Harahap, Kemala Jeumpa

DOI: https://doi.org/10.31004/abdidas.v2i3.335

kenyamanan dalam pengamatannya. Mural dapat diproduksi baik di dalam maupun luar ruangan. Sejarah mencatat bahwa mural sudah ada sejak jaman prasejarah, yaitu 31.500 tahun silam, yang terdapat di lukisan gua di Lascaux, di selatan Perancis. Di Indonesia sendiri tercatat bahwa lukisan dinding juga sudah ada sejak jaman prasejarah, yaitu di jaman Mesolitikum. Pada saat itu lukisan dinding digunakan sebagai tanda bahwa pernah ada manusia yang telah menghuni dan melangsungkan kehidupan di gua tersebut.

Sejarah seni rupa juga mencatat, lukisan mural yang terkenal adalah Guernica atau Guernica y Luno karya Pablo Picasso, yang dibuat saat perang sipil Spanyol di tahun 1937. Mural ini dibuat dalam rangka memperingati pengeboman tentara Jerman di sebuah desa kecil. Sementara di Indonesia sendiri juga tercatat bahwa ketika perang untuk meraih kemerdekaan, banyak para pahlawan dan masyarakat menggunakan media mural untuk mengobarkan semangat dalam meraih kemerdekaan (Nababan, 2019).

Salah satu upaya yang dapat dilakukan untuk memperbaiki kualitas visual sebuah kawasan adalah dengan seni mural. Selain dianggap memperindah tampilan kawasan, keberadaan gambar-gambar dan warna ini juga dapat memperkuat karakter sebuah kawasan. Oleh sebab itu, keberadaan bangunan sebagai media mural berupa dinding sangat diperlukan. Dinding tidak hanya berfungsi sebagai pembatas ruang, namun juga dapat digunakan sebagai media untuk memperindah ruangan. Mural juga dapat dijadikan sebagai petanda atau penanda identitas suatu tempat (Ramadani \& Sabiruddin, 2018).

Manfaat dalam menggunakan seni mural, sebagai berikut: 1) Meningkatkan Kreativitas. Bukan hanya membuat ruang tampak indah, namun juga memberi nilai lebih pada ruangan tersebut. Dapat merangsang daya seni dan imajinasi pada orang yang melihatnya, kreativitas merupakan kunci utama yang harus dimiliki oleh guru untuk anak usia dini guna menciptakan kegiatan pembelajaran yang menyenangkan (Fitriatien, Ninik Mutianingsih, Restu Ria Wantika, Liknin Nugraheni, \& Eko Sugandi, 2020). 2) Memberi Kesan Dinding yang Luas. Melalui gambar, pola, dan warna tertentu yang ditampilkan oleh lukisan mural di dinding, dapat membuat dinding rumah terkesan lebih luas dan lapang. 3) Media Edukasi. Sering kali lukisan mural juga digunakan sebagai sarana edukasi. Misalnya dengan memberi penyuluhan untuk melakukan sesuatu, baik secara langsung maupun tidak langsung.

Beberapa teknik dalam mebuat seni mural sebagai berikut: 1) Teknik Proyektor. Cara melukisnya ialah dengan memanfaatkan gambar yang keluar dari proyektor dan melukisnya. Dengan hanya mengikuti bentuk bayangan dan mewarnainya, lukisan mural dapat diselesaikan. Untuk menggunakan teknik ini, juga harus memperhatikan pencahayaan yang ada dalam ruangan. Usahakan cahaya yang ada di buat seminim mungkin, agar gambar yang keluar dari proyektor terlihat dengan jelas. 2) Teknik Kertas Karbon. Teknik kedua ini masih dapat 
640 Pendampingan Pembuatan Mural Edukasi sebagai Upaya Meningkatkan Minat Belajar Siswa Sekolah Dasar dengan Konsep Belajar dan Bermain- Zhilli Izzadati Khairuni, Liana Atika, Rumila Harahap, Kemala Jeumpa

DOI: https://doi.org/10.31004/abdidas.v2i3.335

dikategorikan sebagai teknik yang mudah, karena hanya cukup meniru gambar aslinya menggunakan kertas karbon, kertas transfer, atau kertas kopi. Teknik ini sangat direkomendasikan bagi pemula yang masih ragu untuk membuat mural dnegan goresan tangan sendiri. Tetapi, dalam menggunakan teknik ini juga harus berhati-hati karena kertas tidak boleh goyah sedikitpun. 3) Teknik Skala. Dengan menggunakan perbandingan dalam skala tertentu agar gambar dapat diperbesar. Rancanglah terlebih dahulu konsep dinding kamar melalui software desain menggunakan skala yang tepat. Selanjutnya berikan garis-garis vertikal dan horizontal sebagai skalanya. Dan cetak hasil olahan desain tersebut. 4) Teknik Langsung. Teknik yang terakhir adalah teknik yang digunakan oleh pemural profesional dengan alasan menghemat waktu pengerjaan. Karena sudah terbiasa membuat mural, tidak ada kesulitan berarti saat membuat mural dengan konsep yang rumit sekalipun. Hasilnya, tentu saja terlihat indah dan tidak miring. Tetapi bagi yang merasa dirinya masih terbilang pemula, disarankan untuk menghindari teknik ini kalau tidak ingin membuang-buang waktu, biaya dan tenaga yang sudah dikeluarkan dengan percuma.

Kegiatan pengabdian kepada masyarakat dibuat untuk memberikan pemahaman kepada pengelola sekolah serta mendampingi dan memberi pelatihan dalam pembuatan mural. Kegiatan ini di awali dengan pemberian materi dalam sebuah sosialisasi mengenai pengetahuan umum mengenai teknik dan seni mural, potensi mural, serta fungsi mural sebagai unsur estetika yang dapat memperindah bangunan dan menjadikan lingkungan kawasan memiliki daya tarik yang berbeda. Selain memberikan pengetahuan sesuai pada materi yang telah dibagikan, tim pengabdian juga memberi motivasi kepada pengelola dan guru-guru untuk mempelajari pembuatan mural dan manfaat apa yang didapat dari kegiatan PKM ini. Partisipasi warga sekolah dalam kegiatan mural di lingkungan sekolah, menjadi salah satu media pengenalan warga sekolah terhadap pemeliharaan dan menjaga lingkungan menjadi lebih indah dan sehat (Chotib, 2012).

Pemahaman peserta dapat diukur dengan proses tanya jawab. Setelah metode ceramah perkenalan teori maka dilanjutkan dengan memperkenal alat dan bahan apa saja yang akan digunakan pada kegiatan ini. Alat dan bahan dipersiapkan oleh tim pengusul dan panitia pelaksana. Setelah itu dilanjutkan dengan pemberian penjelasan sekaligus mencontohkan proses pembuatan mural pada dinding yang telah ditentukan, dengan metode demonstrasi. Peserta pelatihan langsung praktik pembuatan mural yang didampingi oleh tim pelaksana. Pelaksanaan praktik ini tim pelaksana dibantu 5 orang mahasiswa Prodi Pendidikan Teknik Bangunan UNIMED, yang berperan sebagai asisten instruktur dan Mahasiswa Jurusan Pendidkan Seni Rupa sebagai mitra pada kegiatan PKM. Tugas asisten instruktur adalah membimbing dan mendampingi peserta kegiatan dalam proses pembuatan mural, dan mitra sebagai pembuatan mural sehingga dalam pelaksanaannya lebih mudah dan lancar. 
641 Pendampingan Pembuatan Mural Edukasi sebagai Upaya Meningkatkan Minat Belajar Siswa Sekolah Dasar dengan Konsep Belajar dan Bermain- Zhilli Izzadati Khairuni, Liana Atika, Rumila Harahap, Kemala Jeumpa

DOI: https://doi.org/10.31004/abdidas.v2i3.335

Kegiatan PKM ditujukan kepada pengelola dan guru-guru sekolah. Kegiatan dilakukan mulai dari bulan Juni 2020 survei awal lokasi, dan 14-18 Juli 2020 kegiatan sosialisasi di lokasi sekolah dan proses pembuatan mural dimulai pada 28 Juli 2020 sampai dengan 7 Agustus 2020 dilaksanakan di bangunan terdepan sekolah. Serah terima dilaksanakan pada 10 Agustus 2020 dan kegiatan umpan balik pada 28 Agustus 2020. Pelaksanaan kegiatan PKM pendampingan pembuatan mural ini terdiri dari beberapa tahap, yaitu sebagai berikut:

\section{Sosialisasi Kegiatan dan Diskusi Tema Mural}

Kegiatan sosialisasi dalam bentuk memberikan pengetahuan umum mengenai mural dan bagaimana cara mengaplikasi mural, kegiatan ini juga disertai diskusi untuk mendapatkan kesepakatan dalam menentukan tema mural yang akan diterapkan di dinding sekolah. Kegiatan ini dijelaskan pada gambar 2 berikut ini.

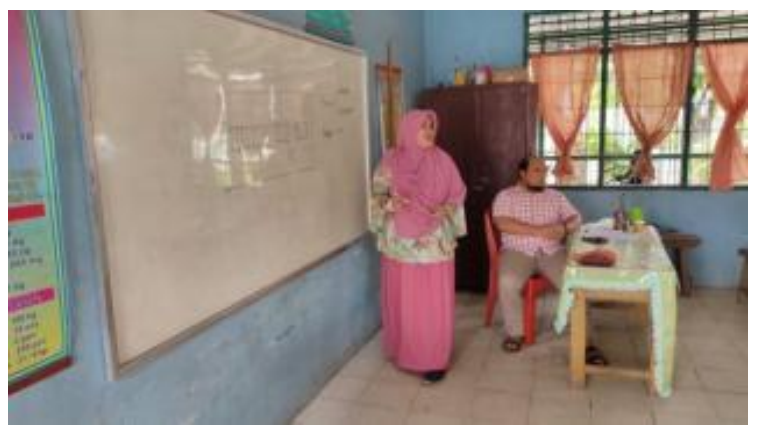

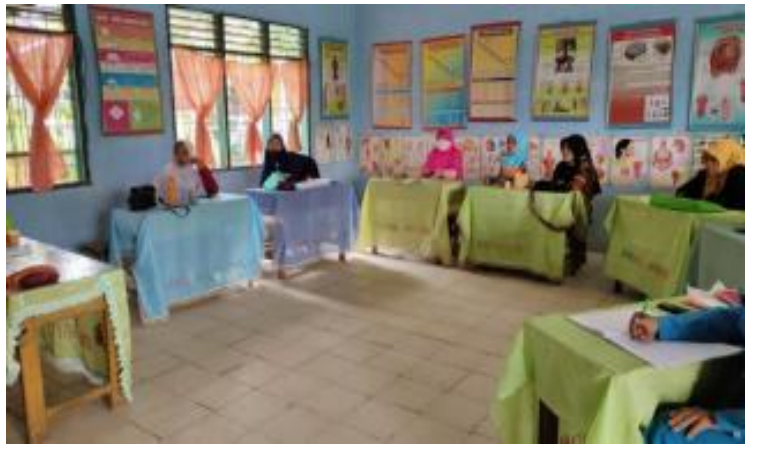

Gambar 2. Kegiatan Sosialisasi dan Diskusi untuk Menentukan Tema Mural

\section{Pembuatan Sketsa Mural}

Setelah melakukan diskusi, Tim PKM beserta mahasiswa membuat sketsa yang menggambarkan ide yang akan diterapkan di dinding sekolah. Tujuan dari sketsa ini untuk memberikan gambaran dari ide-ide peserta PKM yang telah dituangkan pada saat sosialisasi. Hasil dari sketsa ini tentunya tidak akan sama persis, dan akan menyesuaikan kondisi dinding pada

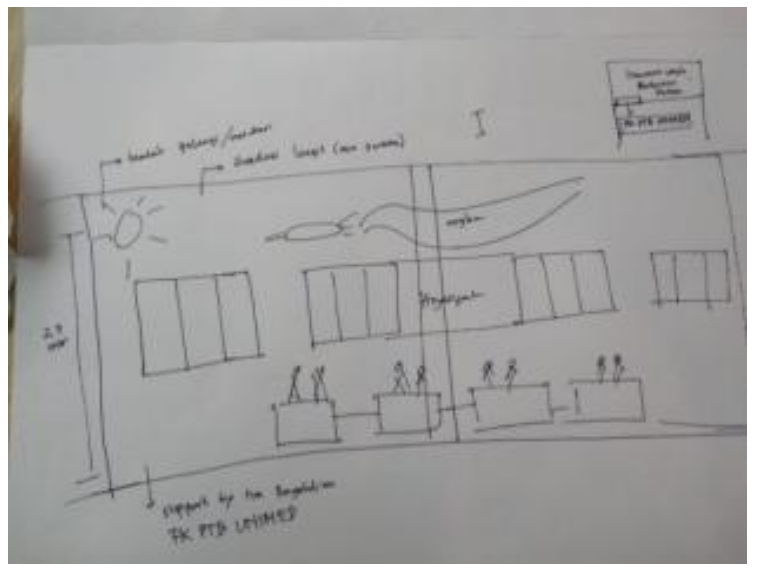


642 Pendampingan Pembuatan Mural Edukasi sebagai Upaya Meningkatkan Minat Belajar Siswa Sekolah Dasar dengan Konsep Belajar dan Bermain- Zhilli Izzadati Khairuni, Liana Atika, Rumila Harahap, Kemala Jeumpa

DOI: https://doi.org/10.31004/abdidas.v2i3.335

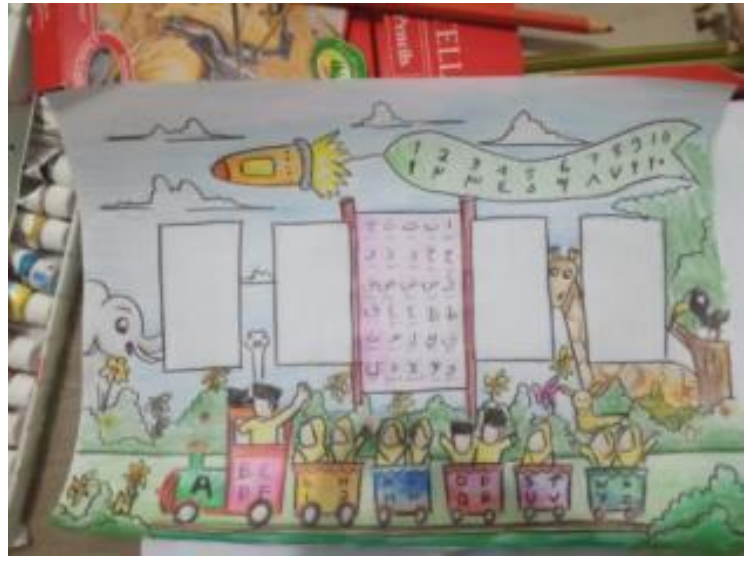

Gambar 3. Sketsa Mural sebagai Ide Dasar dalam Pembuatan Konsep Desain

\section{Persiapan Dinding yang akan Diaplikasikan Mural}

Hal yang paling mendasar dalam membuat mural adalah kondisi dinding yang harus bersih, maka dilakukan teknik pengecatan dasar sebelum konsep dituangkan (gambar 4).
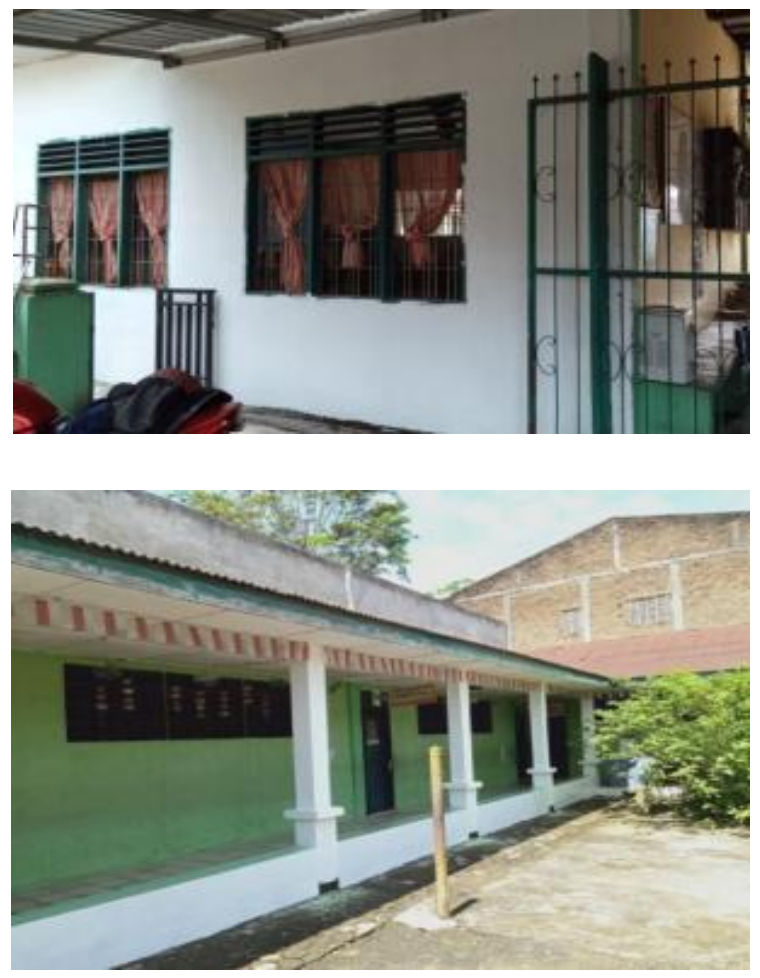

Gambar 4. Proses Pengecatan Dasar Dilakukan oleh Mahasiswa Teknik dan Seni Rupa

\section{Proses Penggambaran}

Kegiatan ini telah melibatkan mahasiswa dari 2 fakultas yaitu mahasiswa teknik dan juga mahasiswa seni, untuk menyelaraskan lintas bidang ilmu serta membuat pengetahuan mahasiswa semakin kaya akan pengalaman. Berikut ini proses penggambaran konsep pada dinding yang sudah di cat dasar (gambar 5).

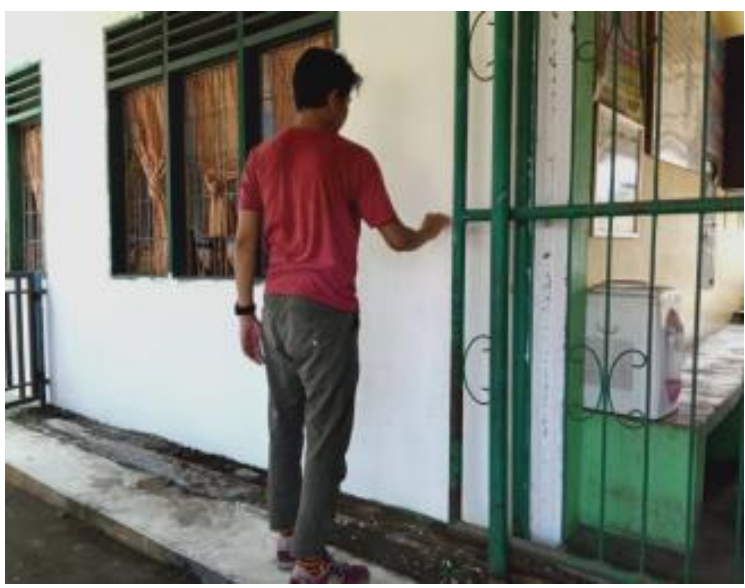

Gambar 5. Proses Pengecatan Dasar Dilakukan oleh Mahasiswa Teknik dan Seni Rupa

\section{Proses Pembuatan Mural dengan Tema Edukasi}

Kegiatan ini sebagian besar telah dikerjakan oleh mahasiswa seni rupa sebagai mitra mural agar kualitas gambar terjaga komposisi dan tetap presisi. Tim pengabdian sebagai pengawas, memberikan arahan serta mendampingi guru-guru dalam mendapatkan informasi pembuatan mural. Bersama-sama dengan guru, pengelola dan mahasiswa teknik serta mahasiswa seni rupa telah transfer ilmu dalam proses penerapan warna-warna cat pada dinding. Kegiatan ini telah di rancang dengan timeline yang baik agar tidak terjadi kerusakan pada produk jika dikerjakan dalam 
643 Pendampingan Pembuatan Mural Edukasi sebagai Upaya Meningkatkan Minat Belajar Siswa Sekolah Dasar dengan Konsep Belajar dan Bermain- Zhilli Izzadati Khairuni, Liana Atika, Rumila Harahap, Kemala Jeumpa

DOI: https://doi.org/10.31004/abdidas.v2i3.335

waktu yang berjarak. Kegiatan ini di selesaikan dalam kurun waktu kurang lebih 2 minggu. Proses kegiatan ini didokumentasikan pada gambar 6 berikut ini.
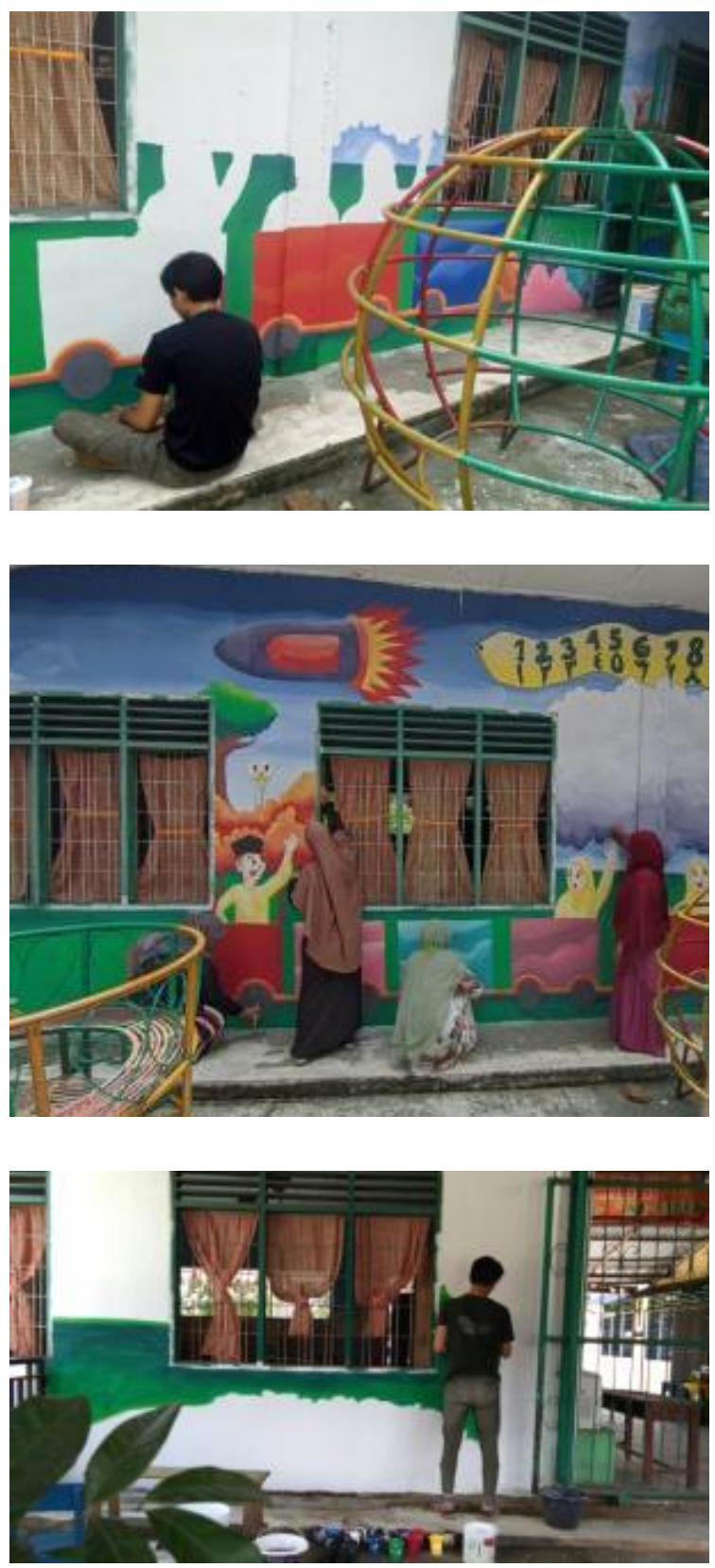

Gambar 6. Kegiatan Transfer Ilmu kepada Guru-

Guru yang Terlibat pada Kegiatan PKM

\section{Evaluasi Kegiatan Pengabdian}

Sebagai evaluasi pelaksanaan kegiatan pengabdian masyarakat pembuatan mural edukasi ini, tim pengabdian melakukan umpan balik. Kegiatan umpan balik dilakukan oleh peserta kegiatan dengan mengisi kuesioner yang berisikan 5 pertanyaan pilihan ganda dan 1 pertanyaan. Pertanyaan-pertanyaan yang diberikan berupa hal apa saja yang diperoleh peserta pengabdian pada kegiatan pembuatan mural edukasi ini. Jawaban berupa pilihan kepuasan para peserta dalam mengikuti kegiatan ini. Sebanyak 10 orang responden yang mengisi survei terdiri dari pengelola sekolah, guru-guru dan mahasiswa yang terlibat pada kegiatan pengabdian pembuatan mural edukasi. Hasil dari kuesioner yang sudah dirangkum adalah sebagai berikut:

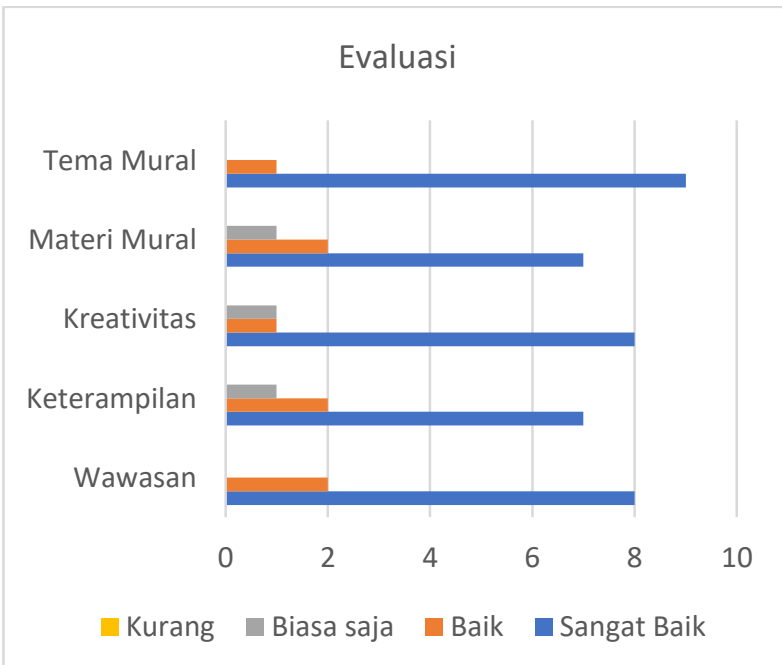

Gambar 7. Tabel Evaluasi sebagai Umpan Balik Kegiatan PKM

Dari pertanyaan pilihan ganda yang diberikan diperoleh hasil sebagian besar peserta bertambah wawasan, keterampilan dan kreativitas 
644 Pendampingan Pembuatan Mural Edukasi sebagai Upaya Meningkatkan Minat Belajar Siswa Sekolah Dasar dengan Konsep Belajar dan Bermain- Zhilli Izzadati Khairuni, Liana Atika, Rumila Harahap, Kemala Jeumpa

DOI: https://doi.org/10.31004/abdidas.v2i3.335

pada kegiatan ini, sehingga para peserta sangat tertarik dan antusias untuk mengikuti kegiatan tersebut. Dari pertanyaan uraian yang diberikan mengenai kritik dan saran pada kegiatan pembuatan mural, para peserta menilai kegiatan ini sangat positif dan berharap dengan adanya tampilan visual baru pada sekolah, para guru dan murid semakin semangat dalam belajar sehingga dapat menciptakan prestasi yang baik untuk mengenalkan sekolah kepada masyarakat, sehingga semakin banyak murid yang tertarik pada sekolah ini.

Dengan adanya umpan balik yang positif pada kegiatan ini, potensi keberlanjutan kegiatan pembuatan mural ini bisa dilakukan pada lokasi yang lain dengan konsep atau tema yang berbeda sehingga semakin banyak masyarakat yang mendapat edukasi dan keterampilan dalam memperbaiki visual bangunan.

\section{SIMPULAN}

Proses kegiatan dilakukan oleh beberapa dosen sebagai tim pengabdian dengan melibatkan mahasiswa agar ilmu dan pengetahuan dapat diaplikasikan langsung ke masyarakat. Kegiatan pengabdian kepada masyarakat ini juga sebagai bentuk aktivitas dosen dalam menerapkan nilainilai ilmu pengetahuan yang sudah didapat. Pengabdian masyarakat berupa pembuatan mural di sekolah ini terlaksana dengan baik sesuai dengan yang telah direncanakan.

Dari hasil sosialisasi sampai dengan proses pengerjaan para peserta PKM sangat antusias dan sangat senang bisa mempelajari cara-cara dalam pembuatan mural, dimana peserta mendapat keterampilan baru yang belum pernah diperoleh sebelumnya sebagai bekal dalam membuat suatu inovasi juga memberi warna baru pada tampilan visual sekolah sehingga membuat semangat dalam proses belajar mengajar. Hal ini dilihat dari hasil evaluasi berupa umpan balik kepada peserta kegiatan pengabdian pembuatan mural edukasi. Dampak positif bagi tampilan visual yang baik ini menambah kesan yang terlihat lebih indah dan ceria, selain itu dampak dari aspek psikologi diharapkan dapat menambah minat belajar serta minat mengajar guru-guru semakin meningkat dan proses edukasi dalam bentuk mural ini bisa dimanfaat untuk pengetahuan.

\section{UCAPAN TERIMA KASIH}

Ucapan terima kasih disampaikan kepada Lembaga Penelitian dan Pengabdian Masyarakat (LPPM) UNIMED pada program PKM PNBP 2020, yang sangat mendukung program pengabdian ini berlangsung dengan baik. Serta dukungan dari Jurusan Pendidikan Teknik Bangunan Fakultas Teknik dan Fakultas Seni Univesitas Negeri Medan. Kepada Sekolah SDI Ar-ridha yang sudah bersedia menjadi mitra kegiatan pengabdian kepada masyarakat.

\section{DAFTAR PUSTAKA}

Chotib, Sjahidul Haq, 2012, Kajian Seni Mural/ Graffity sebagai media informasi dan sosialisasi program sekolah yang peduli dan ber-wawasan lingkungan, Madinah, 8(2), 111.

Fitriatien, S. R., Ninik Mutianingsih, Restu Ria Wantika, Liknin Nugraheni, \& Eko Sugandi. 
645 Pendampingan Pembuatan Mural Edukasi sebagai Upaya Meningkatkan Minat Belajar Siswa Sekolah Dasar dengan Konsep Belajar dan Bermain- Zhilli Izzadati Khairuni, Liana Atika, Rumila Harahap, Kemala Jeumpa

DOI: https://doi.org/10.31004/abdidas.v2i3.335

(2020). Pengenalan Konsep Matematika pada Anak Usia Dini melalui Lagu. Dinamisia: Jurnal Pengabdian Kepada Masyarakat, 4(2), 311-321. https://doi.org/10.31849/dinamisia.v4i2.3939

Hantono, D., Ashadi, Purwantiasning, A. W., Anisa, Nur'aini, R. D., \& Sari, Y. (2020). Pengadaan Taman Bermain Anak Untuk Peningkatan Kualitas Pendidikan di Madrasah Ibtidaiyah Nurul Huda II Dusun Gunung Leutik Kabupaten Bogor. Dinamisia: Jurnal Pengabdian Kepada Masyarakat, $\quad 4(2), \quad 236-241$. https://doi.org/10.31849/dinamisia.v4i2.3897

Harani, A. R., \& Motic, K. (2017). Pengaruh Fasade Bangunan Terhadap Karakter Visual Kawasan (Studi Kasus: Pecinan Semarang, Malaysia dan Singapura). Jurnal Pengembangan Kota, 1-8.

Nababan, R.S., (2019). Karya Mural Sebagai Medium Mengkritisi Perkembangan Jaman (Studi Kasus Seni Mural Karya Young Surakarta) Proceeding: International Conference on Art, Design, Education, and Cultural Studies (ICADECS)

Ramadani, F. R., \& Sabiruddin, H. (2018). Peran Sosial Dalam Seni Mural di Kota Samarinda. e-Jurnal Ilmu Komunikasi UNMUL.

Thamrin, N. H., \& Noviana, M. (2020). Pendampingan Pembuatan Mural Sebagai Upaya Perbaikan Visual Kawasan Loa Buah, Samarinda Kota Samarinda, Aksiologiya: Jurnal Pengabdian Kepada Masyarakat 4(1), 91-99.

Wahyudi, A. T., Natadjaja, L., Wicandra, O. B., Waluyanto, H. D., (2017). Kajian Partisipasi Masyarakat dalam Kegiatan Mural (Studi Kasus: Mural Dinding Sekolah TK YBPK Sekar Indah Malang), NIRMANA, 17(2),8795. https://doi.org/10.9744/nirmana.17.2.8795

Yasa, A. D. (2020). Membudayakan Keterampilan Menulis pada Mading Kelas untuk Melatih Kreativitas Siswa. DIKEMAS (Jurnal Pengabdian Kepada Masyarakat), 4(2), 242249. https://doi.org/10.32486/jd.v4i2.490
Yusuf, A. W., (2014). Partisipasi masyarakat dalam pembangunan kota yang berkelanjutan dan berkeadilan, Administrasi Publik, 11(2), 58 . 